\title{
The Anti-Allergic Effects of FPL 52694
}

\begin{tabular}{|c|c|}
\hline E. & Wells \\
\hline R.P. & Eady \\
\hline S.T. & Harper \\
\hline M.E. & Mather \\
\hline P.A. & Riley \\
\hline
\end{tabular}

Fisons plc - Pharmaceutical Division, Science and Technology Laboratories, Loughborough, UK

\section{Abstract}

The substituted chromone carboxylic acid FPL 52694 inhibited models of IgE-mediated immediate hypersensitivity reactions in the rat by a mechanism similar to that of sodium cromoglycate. The compound was more potent than sodium cromoglycate but unlike cromoglycate was active following oral administration.

Correspondence to: Dr. R.P. Eady, Fisons Pharmaceutical Division, Bakewell Road, Loughborough, Leicestershire, LE 11 ORH (UK)

It has been reported that FPL 52694 (5-[2-hydroxy-propoxy]-4-oxo-8-propyl-4H-1 -benzopyran2-carbox-ylic acid sodium salt) inhibits the secretion of gastric acid in volunteers [1] and animals [2]. It has been suggested that the suppression of gastric acid secretion following infusion with pentagastrin is due to the ability of the compound to inhibit histamine release within the gastric mucosa [2]. This communication presents the evidence showing that FPL 52694 inhibits mediator release from mast cells challenged with antigen or antibody to IgE, and that the mechanism of mast cell stabilisation is similar to that for sodium cromoglycate.

For a number of years, the immediate hypersensitivity reaction to egg albumin in rats passively sensitised with serum containing IgE antibodies to egg albumin, the passive cutaneous anaphylaxis test (PCA) [3], has been used as a screen to evaluate anti-allergy compounds [4]. FPL 52694 administered intravenously, 1 min before antigen challenge, inhibited the PCA reaction in a dose-dependent manner. Results from two experiments showed that FPL 52694 was approximately twice as potent as sodium cromoglycate, having an ED50 value of $0.8 \mathrm{mg} / \mathrm{kg}$. However, unlike sodium cromoglycate, FPL 52694 was shown to inhibit the PCA reaction in rats when administered orally $7 \mathrm{~min}$ before antigen challenge (50\% inhibition at $20 \mathrm{mg} / \mathrm{kg}$ ) or when administered directly into the duodenum of anaesthetised laparotomised rats $7 \mathrm{~min}$ before antigen challenge (50\% inhibition at $12.5 \mathrm{mg} / \mathrm{kg}$, mean of two experiments).

Several workers [5-9] have reported the beneficial effects of sodium cromoglycate, administered orally, in patients with food allergy, and from the work of Paganelli et al. [10] it has been suggested that sodium cromoglycate was inhibiting local intestinal anaphylaxis, preventing an increase in intestinal permeability. We have examined several chromones in the model of intestinal anaphylaxis described by Byars and Ferraresi [11]. Rats were sensitised to egg albumin [3] and challenged 4 weeks later by administering antigen $(1 \mathrm{mg})$ intraduodenally to anaesthetised laparotomised animals. A change in capillary permeability was measured by injecting intravenously, 15 min before antigen challenge, 125-iodinated-Bovine serum albumin. 
15 min after antigen challenge, the radioactive content of the intestine was measured. The increase in capillary permeability following antigen challenge was inhibited by the administration of sodium cromoglycate, intraduodenally, but results were highly variable and inhibition was only observed at high doses $(400 \mathrm{mg} / \mathrm{kg}$, administered simultaneously with antigen).

However, in a direct comparison with sodium cromoglycate, FPL 52694 was shown to be at least four times more potent than cromoglycate in this model of intestinal anaphylaxis.

Compound 48/80 administered intravenously in rats causes the widespread degranulation of mast cells which can be quantitated by staining the subcutaneous connective tissue with toluidine blue [12]. The degree of degranulation can be inhibited by injecting

The Anti-Allergic Effects of FPL 52694

189

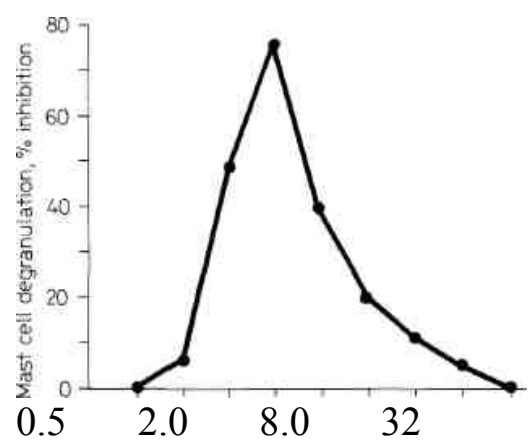

Dose FPL $5269 \Lambda, \mathrm{mg} / \mathrm{kg}$

Fig. 1 Inhibition of subcutaneous mast cell degranulation induced by Compound $48 / 80(0.5 \mathrm{mg}$ kg"1 i.v. $)$ in male Sprague Daw-ley rats $(100 \mathrm{~g} ; \mathrm{n}=6)$.

FPL 52694, intravenously, 1 min before Compound 48/80. As shown in figure 1, a bell-shaped dose response is observed similar to that found for sodium cromoglycate [13].

FPL 52694 was compared with sodium cromoglycate for its ability to inhibit degranulation of unpuri-fied rat peritoneal mast cells challenged in vitro with anti-rat $\operatorname{IgE}$ (Miles) as previously decribed [14]. By comparing the concentrations required to give half maximum inhibition, FPL 52694 was shown to be 15.4 times more potent than sodium cromoglycate in blocking histamine release (range 14.3-19.9 in three experiments). Typical dose response curves are shown in figure $2 \mathrm{a}$.

Sodium cromoglycate has been shown to induce the phosphorylation of a 78,000-molecular weight protein in rat peritoneal mast cells, in the absence of challenge [15], and induction of this phosphorylation event correlates well with the ability of anti-allergic chromones to inhibit histamine release [14]. Phosphorylation of this same protein also occurs late in the challenge sequence and it has been proposed that this represents the natural feedback mechanism which restabilises the mast cell [16]. Sodium cromoglycate thus appears to inhibit mediator release by inducing this natural switch-off mechanism. Using the methodology previously reported [14], FPL 52694 also induced phosphorylation of this 78,000-molecular weight protein (fig. 2b), at similar concentrations to those required to inhibit histamine release.

In summary, FPL 52694 has been shown to inhibit type I immediate hypersensitivity reactions in the skin and intestine of rat. Further, this compound inhibits degranulation and mediator release from rat mast 


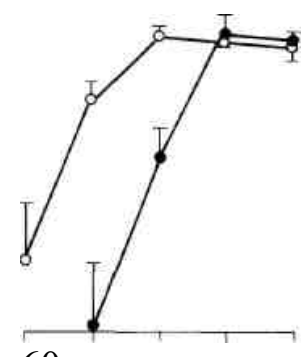

60

40

FPL 52694

Sodium cromoglycate

20

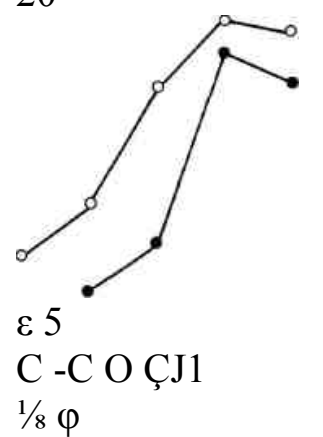

a. E 0

$10-\mathrm{f}$

10-7 10-6 10"

Concentration, $\mathrm{M}$

Fig. 2. a Inhibition of histamine release induced by anti-rat $\operatorname{IgE}(1 / 2,000$ dilution, Miles). Drugs were added at the time of challenge. The unblocked release was $21 \%$ of total histamine. $b$ Phosphorylation of the 78,000 molecular weight protein after a 30 -sec-ond incubation of [32P]orthophosphate loaded purified mast cells with compound. Proteins were fractionated by SDS polyacryla-mide gel electrophoresis and the peak height on a denisitometric scan of the autoradiograph used as a measurement of phosphorylation.

cells by a similar mechanism to that of sodium cromoglycate. The compound appears to be more potent than sodium cromoglycate and is absorbed after oral administration. It is possible that the mast cell-stabilising properties of FPL 52694 account for the ability of the compound to inhibit gastric acid secretion in animals and man, by preventing histamine release from cells within the gastric mucosa.

References

Alban Davies, H.; Rhodes, J; Thomas, M: Inhibition of gastric acid secretion with a mast cell stabiliser, FPL 52694. Br. J. clin. Pharmacol/: 53-56(1981).

Nicol, A.K.; Thomas, M.; Wilson, J.: Inhibition of gastric acid secretion by sodium cromoglycate and FPL 52694. J. Pharm. Pharmac. 33: 554-556(1981).

Goose, J.; Blair, A.M.J.N.: Passive cutaneous anaphylaxis in the rat, induced with two homologous reagin-like antibodies and its specific inhibition with disodium cromoglycate. Immunology 16: 749(1969).

190

Wells/Eady/Harper/Mather/Riley 
Cairns, H.: Models for the development of anti-asthmatic drugs; in Pepys, Edwards, The mast cell, its role in health and disease, p. 172 (Pitman Medical, London 1979)

Pannaeus, A.; Foucard, T.; Johansson, S.G.O.: The effect of orally administered sodium cromoglycate on symptoms of food allergy. Clin. Allergy 7; 109-115 (1977).

Gerrard, J.W.: Oral cromoglycate: its value in the treatment of adverse reactions to food. Ann. Allergy 42: 135-138 (1979).

Kocoshis, S.; Gryboski, J.D.: Use of cromolyn in combined gastrointestinal allergy. J. Am. med. Ass. 242: 1169-1173 (1979).

Wraith, D.G.; Brostoff, J.; Carini, C: Adverse reactions to foods. Clinical characteristics, dietary exclusion challenge data and RAST in a group of food sensitive patients and the role of sodium cromoglycate. Folia allergol. immunol. Clin. 29: 456-462(1982).

Ortolani, C; Pastorello, E.; Zanussi, C: Prophylaxis of adverse reactions to foods: a double-blind study of oral sodium cromoglycate for the prophylaxis of adverse reactions to foods and additives. Ann. Allergy 50: 105-109 (1983).

Paganelli, R.; Levinsky, R.J.; Brostoff, J.; Wraith, D.G.: Immune complexes containing food proteins in normal and atopic subjects after oral challenge and effect of sodium cromoglycate on antigen absorption. Lancet ii: 1268-1270(1979).

Byars, N.E.; Ferraresi, R.W.: Intestinal anaphylaxis in the rat as a model of food allergy. Clin. exp. Immunol. 24: 352-356 (1976).

Orr, T.S.C.; Hall, D.E.; Gwilliam, J.M.; Cox, J.S.G.: The effect of disodium cromoglycate on the release of histamine and de-

granulation of rat mast cells induced by Compound 48/80. Life Sci. 10: 805-812(1971).

Orr, T.S.C.; Cox, J.S.C.: The mast cell and asthma in Intal in bronchial asthma, pp. 1-16. 8th Int. Congress of Allergology, Tokyo (ed. Pepys, J. and Yamamura, Y., Fisons Pharmaceuticals 1973).

Wells, E.; Mann, J.: Phosphorylation of a mast cell protein in response to treatment with antiallergic compounds. Biochem. Pharmac. 32: 837-842(1983).

Theoharides, T.C.; Sieghart, W.; Greengard, P.; Douglas, W.W.: Antiallergic drug cromolyn may inhibit histamine secretion by regulating phosphorylation of a mast cell protein. Science 207: 80-82(1980).

Sieghart, W.; Theoharides, T.C.; Alper, S.L.; Douglas, W.W.; Greengard, P.: Calcium-dependent protein phosphorylation during secretion by exocytosis in the mast cell. Nature, Lond. 275: 329331(1978). 